\title{
Patents and Corporate Credit Risk
}

\author{
Carl Benedikt Frey ${ }^{1}$, Peter Neuhäusler ${ }^{2,3}$, Knut Blind ${ }^{3}$ \\ 1 University of Oxford, Oxford Martin School, 34 Broad St, Oxford, OX1 3BD, United Kingdom, \\ carl.frey@oxfordmartin.ox.ac.uk \\ 2 Fraunhofer Institute for Systems and Innovation Research ISI, Breslauer Straße 48, 76139 Karlsruhe, Germany, \\ peter.neuhauesler@fraunhofer.isi.de \\ 3 Berlin University of Technology, Chair of Innovation Economics, Müller-Breslau-Straße 14, 10623 Berlin, Ger- \\ many, knut.blind@tu-berlin.de
}

\begin{abstract}
A vast literature documents a positive relationship between patents and companies stock market performance. Nevertheless, evidence on the influence of patents on companies' debt capacity remains sparse. In this paper, we examine the relationship between companies' patent portfolios and their credit rating, providing relevant, albeit indirect, evidence on patents as a debt funding mechanism. Using a panel dataset on 155 U.S. firms, we find a positive relationship between companies' credit rating and the size of their patent portfolio. Our indicators for valuable patents, however, provide a mixed picture. While there is a positive link between the average family size of a company's patent portfolio and its credit ratings, we surprisingly find a significant negative relationship between patent forward citations and companies ratings. We hypothesize that this finding is the result of citations being associated with patent lawsuits, potentially incurring substantial losses on creditors.
\end{abstract}

Keywords: corporate credit ratings, patents, credit risk, R\&D, corporate finance 


\section{Introduction}

A substantial body of work documents the impact of patents on companies' stock market performance (Griliches (1981); Pakes, (1986); Bloom and Van Reenen (2002); Hall et al. (2005)). Specifically, patent counts are associated with higher estimates of Tobin's q, and patents themselves contain a wealth of information about their economic value (Jaffe and Trajtenberg (2002)). For example, companies with more cited patents typically experience better stock market performance (Griliches (1990)), and patents filed across a larger number of jurisdictions tend to be of higher value (Harhoff (1999)).

Importantly, while patents constitute real options for shareholders, they are sometimes also used as collateral by creditors. As recently reported by The Financial Times, US banks are gradually seeking pathways to use the intellectual property holdings of their borrowers as collateral (Masters (2012)). In particular, following its 2011 bankruptcy, Nortel raised money for its creditors by selling the group's wireless patents for 4.5 billion USD, showing that patents can secure repayment. Yet, despite the recent attention in the financial press, the literature examining the relevance of patents to corporate lenders is surprisingly sparse. Against this background, we explore the relationship between companies' patent portfolios and their creditworthiness, using a panel of 155 U.S. firms receiving credit ratings from Standard \& Poor's between 1990 and 2007.

Our study builds on a vast literature arguing that under the presence of incomplete contracts, collateral can improve a company's financial capacity (Barro (1976); Stiglitz and Weiss (1981); Hart and Moore (1994)). Crucially, collateral eases financing ex ante, by acting as a disciplining device on borrowers', giving creditors the option to liquidate pledged assets ex post. The role of asset liquidation in increasing companies' debt capacity also has macroeconomic ramifications. 
Because a firm's borrowing capacity depends on the collateral value of its assets, and asset values tend to deteriorate in business downturns, the "collateral channel" amplifies the effect of real shocks by reducing investment (Bernanke and Gertler, 1989; Kiyotaki and Moore, 1997). As intangible assets-such as of technologies and brands-constitute an ever increasing share of companies' asset values (Lev (2000)), intellectual property rights could in theory become the next collateral channel (Loumioti (2012)). Without a better understanding of how patents impact on the credit risk taken on by corporate lenders, however, conclusions about the potential of patents to secure repayment seem premature.

Despite the contribution of patents to companies' stock market performance, the impact of patents on companies' debt capacity is not evident. This is because debt and equity contracts are fundamentally different, leading shareholders and creditors to account for uncertainty differentially. When dealing with patents-constituting real options on R\&D projects-uncertainly is often particularly problematic, as the vast majority of innovation efforts fail (Mansfield et al. (1977)). Because creditors do not share the upside of the firm's investments, they are mainly concerned with the bottom tail of the distribution of economic returns. As a result, creditors will want to raise interest rates in order to compensate for additional risk-taking, leading unmonitored borrower's to invest in high-risk projects to cover their costs of borrowing. This, in turn, increases the probability of default without offsetting higher gains to the creditor in case of success. Hence, the debt financing of $R \& D$ projects is associated with moral hazard complications (Stiglitz (1985)), and adverse selection, as higher interest rates can prompt low risk borrowers to exit the market (Stiglitz and Weiss (1981)). Conversely, equity funding does not require any collateral, nor does it cap the upside of investors' returns, implying that stock markets favor invest- 
ments in innovation relative to credit markets. By examining the relationship between companies' patent portfolios and their creditworthiness we seek to provide relevant, albeit indirect, evidence on patents as a debt funding mechanism.

In our empirical analysis, we specifically focus on the relationship between companies' patent portfolios and their credit ratings, reflecting the opinion of credit rating agencies about a company's creditworthiness. Because the successful sale of debt securities depends on these agencies initial assessment of the underlying collateral, our analysis offers insights about the impact of patents on companies creditworthiness, and their ability to tap into credit markets. Importantly, we find that corporate credit ratings-as stock market valuations-reflect the future economic benefits of a larger patent portfolio. Our indicators for valuable patents, however, provide a mixed picture. While there is a positive link between the average family size of a company's patent portfolio and its credit ratings, we surprisingly find a significant negative relationship between patent forward citations and companies ratings. We hypothesize that this finding is the result of citations being associated of patent lawsuits (Lanjouw and Schankerman (2001)), potentially incurring substantial losses on creditors (Bessen and Meurer (2008)). Our results are robust to various specifications, such as controlling for firm size, ROA, leverage, subordinated debt, etc.

Our study is related to several literatures. First, in an important contribution, Czarnitzki and Kraft (2004) show that R\&D expenditures and patents of German companies have an inverted Ushaped relationship with their credit rating. We build on this finding using a set of patent value indicators, allowing us to differentiate commercially valuable patents. Our approach also departs from the studies of Griffin et al. (2018) and Hsu et al. (2015), which consider how companies' innovation performance (i.e., patent output per dollars spent on R\&D) is reflected in their credit 
rating and bond pricing, respectively. In contrast, we focus on the value of patents from a creditor perspective (i.e. as collateral) rather than companies innovation performance.

Second, we build on a vast literature examining the perceived financial value of patents by stock markets (Griliches (1981); Pakes, (1986); Bloom and Van Reenen (2002); Hall et al. (2005)). While we are unable to make causal interpretations about rating agencies perceived value of patents, we add to this literature by shedding additional light on the relationship between patents and companies' creditworthiness. Because the creditworthiness of R\&D-intensive companies' influences the willingness of creditors to channel capital to innovation projects, this is a question of crucial policy importance.

Third, we build on the literature examining the relationship between patents and firm survival (Jensen et al. (2006); Helmers and Rogers (2010); Cockburn and Wagner (2010)). While Jensen et al. (2006) find a significant relationship between patents and firm survival, Cockburn and Wagner (2010) show that patenting is positively associated with firm survival, although cited patents may make companies more attractive acquisition targets. Furthermore, Helmers and Rogers (2010) document that new firms with at least one patent experience a 13.9 percent lower probability of exit, possibly reflecting that companies that acquire patents are more likely to obtain funding (Cockburn and MacGarvie, 2009). We build on these findings by examining if the mitigating effects of patents on company exits are reflected in their creditworthiness.

The remainder of this paper is structures as follows. In section 2, we review the literature on patents and corporate credit risk. Section 3 describes our data sources and methods. In section 4, we discuss our main findings. Finally, in section 5, we derive some conclusions and implications for policy. 


\section{Financing Corporate R\&D: Patents and Credit Risk}

In this section, we review the literature on innovating companies financing choices and the relevance of patents as a debt funding mechanism. We then turn to explore contrasting evidence on the relationship between companies' patent portfolios and their credit risk.

\section{Literature}

A growing literature has taken interest the financing of corporate R\&D. While most of this work has focused on financing constraints, some studies have also examined innovating firms financing choices. For example, in a seminal contribution, Rajan and Zingales (1995) document that companies with more intangible assets-implied by their market-to-book ratio-are less leveraged. More direct evidence on this relationship is also provided by Aghion et al. (2004), showing that firms' use of debt declines with their R\&D-intensity, as well as Carpenter and Petersen (2002), documenting that small high-tech companies obtain little debt finance.

The relatively low leverage exhibited by innovating companies contrasts predictions of the pecking order proposed by Myers and Majluf (1984), suggesting that under asymmetric information, companies will prefer debt to equity. Because R\&D projects are associated with information asymmetries (Aboody and Lev (2000)), leading stock markets to systematically undervalue innovating companies (Eberhardt et al. (2004)), these should in theory issue debt to finance their investments, to avoid dilution costs of the initial shareholders equity. R\&D intensive companies' reliance on equity to finance $R \& D$ thus posts an empirical conundrum, suggesting that innovating companies prefer issuing undervalued equity to debt.

A possible explanation is that creditors constrain lending to innovating companies. In particular, 
banks and other financial institutions typically prefer to use redeployable assets-whose value in an alternative use is almost as high as in their current use (Williamson (1988))-to secure loans. Because R\&D investments are associated with company-specific tacit knowledge, and provide limited inside collateral, the sunk costs associated with R\&D are higher than that for ordinary investment (Hall and Lerner (2010)). Empirical support for this idea is provided by Alderson and Betker (1996), documenting that liquidation costs and R\&D are positively related across firms.

While there are instances where patents have secured repayment, the US regulatory environment does not allow for the use of patents as collateral. ${ }^{1}$ Asset-backed lending may, however, not be required for companies to tap into credit markets. Because credit ratings have an independent effect on companies capital structure (Kisgen (2006); (2009))-implying that companies respond to shifts in the cost of credit experienced across various rating categories-innovating companies may improve their debt capacity by securing patent rights on their inventions. Importantly, as shown by Czarnitzki and Kraft (2004), patenting companies systematically receive higher credit ratings, although this relationship has an inverted U-shape. Accordingly, companies will improve their credit rating-and thus their ability to access credit-by patenting their inventions, but only up to a certain point. ${ }^{2}$

In essence, corporate credit ratings constitute opinions about bond-issuing companies' creditworthiness-that is, the likelihood that a company will be able to amortize its debt and fulfil its interest payments. While a key component of credit rating analysis is the evaluation of historical data,

\footnotetext{
1 Typically, patents do not meet regulatory capital assets requirements as they are considered too difficult to value. Banks have however started to find ways to use patents as collateral by structuring deals in which an insurer agrees to buy a borrower's patents at a fixed price in case of default (Masters (2012)).

${ }^{2}$ Griffin et al. (2018) also finds that corporate innovation performance, measured by patent approvals and patent citations divided by $\mathrm{R} \& \mathrm{D}$ expenditures, is associated with a higher future credit rating.
} 
rating opinions are designed to be forward looking (Standard and Poor's (2008)). In other words, ratings take into account not only the present situation but also the potential impact of future events on credit risk. In particular, for companies to service its debt there must be prospects of future cash flows. An essential component of the credit rating process is thus the evaluation of cash flow-relevant business fundamentals. Because patenting companies are better able to appropriate the returns from their investments and typically experience higher survival rates (Audretsch and Lehmann (2004); Helmers and Rogers (2010)), patents provide forward-looking information about companies creditworthiness.

Nevertheless, patens may impact on companies' credit rating in different ways. Although corporate credit ratings incorporate industry- and company-specific factors-that cannot be generalized across companies and industries-Standard \& Poor's corporate credit rating methodology outlines a number of patent-related indicator that are accounted for in credit risk assessments. First, the licensing of any intellectual property rights constitute a part of companies operating income, and is thus directly accounted for in their EBITDA (Standard \& Poor's (2008)). Second, patents can provide meaningful barriers to entry. When evaluating the competitive risk for a company and making future growth projections, patents can provide a part of that analysis (Frey, 2013). Third, Standard \& Poor's makes analytical adjustments for litigation risk. Such adjustments are typically based on case-by-case judgments regarding the probability of a negative outcome in litigation cases (Standard \& Poor's (2008)). Furthermore, as the risk of patent litigation varies substantially across industries, patent litigation risk is sometimes accounted for as an industry-specific risk. For example, Standard \& Poor's (2013) notes that "heath care equipment companies are more commonly affected by risks associated with patent litigation and product liability than compa- 
nies in most industries. Profits may be hurt by the loss of patent protection, costs of patent litigation, and penalties for patent infringement." A litigious patent environment can thus impact negatively on a company's rating (Frey, 2013).

While Czarnitzki and Kraft (2004) and Griffin et al. (2018) have explored the relationship between patents and companies creditworthiness, empirical work examining the link between patents and credit risk remains sparse. In particular, patents may impact on companies' credit rating in very different ways across companies and industries. Although patents are sometimes associated with higher profits and barriers to entry, cited patents are also associated with a higher risk of patent lawsuits (Lanjouw and Schankerman (2001)), potentially reducing a company's credit rating (Standard \& Poor's (2008)). To provide relevant, albeit indirect, evidence on patents as a debt funding mechanism, we turn to exploring the relationship between companies' patent portfolios and their credit rating.

\section{Research questions}

Although a vast literature documents a positive relationship between patents and firm productivity (Balasubramanian and Sivadasan (2011); Bloom and van Reenen (2002); Greenhalgh and Longland (2005)), a larger patent portfolio is not necessarily associated with more effective appropriation of corporate R\&D (Grindley and Teece (1997); Reitzig (2004)). This is because patent applications are filed with different strategic motives. In addition to protecting products and processes from imitation, companies rely on patents to block competitors, engage in licensing (Cohen et al. (2002); Pitkethly (2001)), and to signal growth opportunities to capital markets (Blind et al. (2006)). Many companies thus inflate their patent portfolios with low value patents for strategic reasons (Blind et al. (2009)), providing a possible explanation for the finding of 
Czarnitzki and Kraft (2004): that patent counts have an inverted U-shaped relationship with companies credit rating. Nevertheless, Audretsch and Lehmann (2004) as well as Helmers and Rogers (2010) show that companies with larger patent portfolios exhibit higher survival rates. Possibly, this reflects portfolio size effects, meaning that companies with a large portfolio of patents can more effectively use them as bargaining chips if sued for infringement by a third party. In support of this view, Lanjouw and Schankerman (2001) find evidence of size effects in enforcing patent rights: a larger patent portfolio reduces the probability of lawsuits on any individual patent. Against this background, we ask the question:

\section{Q1: Do companies with larger patent portfolio receive higher credit ratings?}

Because patents differ substantially in their economic value (Gambardella et al. (2008)), patent counts (or patent stocks) can give a distorted impression of the value of a company's patent portfolio. From a credit risk perspective, this means that patent valuation is essential, as only some patents are likely to secure repayment. A widely used indicator for patent value is patent forward citations (Hall et al. (2005); Harhoff et al. (1999; 2003); Narin et al. (1987); Trajtenberg (1990)). Because forward citations (citations a patent receives) relate to previous prior art, conclusions can be made concerning the inventive step and novelty of the invention. A citation in this sense means that the patent is still relevant since it provides an important part of the prior art. Forward citations thus imply a higher degree of technological significance (Albert et al. (1991); Blind et al. (2009); Carpenter et al. (1981)), translating into higher stock market valuations (Hall et al. (2005)). At the same time, however, Lanjouw and Schankerman (2001) find a positive relationship between forward citations and the probability of patent infringement, suggesting that forward citations may have a negative impact on companies' credit rating. We explore this relation- 
ship by asking the question:

Q2: Do companies with a higher share of cited patents receive higher credit ratings?

Furthermore, expanding the geographical scope of patent protection is associated with additional application and maintenance fees. Applications for patent protection abroad can thus be seen as an investment in anticipation of future profits in foreign markets. Following this intuition, patent family size-that is, the number of countries in which the patent has been filed (Putnam (1996))has been used in several studies, documenting a link between patent value and the size of patent family (Harhoff et al. (2003); Lerner (1994); Putnam (1996); Lanjouw, Pakes, Putnam (1998)). From a credit risk perspective, patent portfolios with a larger family size are thus associated with higher immediate costs, which may translate into future profits. We explore the relationship between family size and companies' credit rating by asking:

\section{Q3: Do companies with a higher average patent family size receive higher credit rat-} ings?

\section{Data and sample statistics}

For our empirical analysis, we constructed a panel dataset from three sources (a) the DTIScoreboard; (b) Standard \& Poor's COMPUSTAT North America database; and (c) the EPO Worldwide Patent Statistical Database (PATSTAT). From the DTI-Scoreboard, data on R\&D expenditures and sales was compiled for 479 companies over the period 1990 to $2007 .{ }^{3}$ Specifi-

\footnotetext{
${ }^{3}$ The DTI-Scoreboard is an annual ranking of firms according to their R\&D expenditures. It was initially been setup by the UK Department of Trade and Industry. A later version of the Scoreboard has been published by the Department for Business, Innovation and Skills (BIS). Now the Scoreboard is published as the "EU Industrial R\&D
} 
cally, we use the 2001 DTI-Scoreboard listing 500 companies. Data on the preceding and following years was added from the previous and subsequent scoreboards. If any of the 500 companies had not been listed in the years before or after 2001, the respective observations were treated as missing. Our data is thus in the form of an unbalanced firm-level panel.

In the case of mergers and acquisitions (M\&A) between DTI-listed companies, the data for the respective firms was merged into one annual observation. Using this approach, firms were treated as if they were merged from the beginning of the observation period, ${ }^{4}$ allowing us to preserve comparability over time. ${ }^{5}$ Nevertheless, we are unable to control for M\&A activities with companies that were not DTI-listed. Since the DTI-Scoreboard is a ranking of companies according to their annual $R \& D$ expenditures, our sample is biased towards large firms, i.e. large firms are overrepresented in the sample.

Data on corporate credit ratings and company financials were extracted from Standard \& Poor's COMPUSTAT North America database. All financial indicators were converted to British pounds (GBP) based on a yearly averaged exchange rate-taken from COMPUSTAT Global Currency database-to make them comparable to the DTI-Scoreboard data. Because credit rating data is only available for companies headquartered in the U.S., this reduced our sample size to 3,024 observations from 188 U.S. companies.

Investment Scoreboard" by the European Commission (JRC). Earlier versions that have been used to create the dataset for this analyses can be accessed at the UK Government National Archive: http://webarchive.nationalarchives.gov.uk/20101208170217/http://www.innovation.gov.uk/rd_scoreboard/?p=31

Our dataset is fixed in 2001, where 500 companies were listed in the Scoreboard, to be able to follow these companies up to the year 2007 including name changes and - to a certain extent - M\&A of companies within the Scoreboard.

${ }^{4}$ For details of this method of dataset construction, see Frietsch (2006).

5 This treats merged companies as the sum of its parts, which may be problematic, if mergers and acquisitions caused, for example, synergy effects. 
Patent data was compiled from the EPO Worldwide Patent Statistical Database (PATSTAT), providing detailed patent information from 81 patent offices worldwide. The companies in our dataset were identified via keyword searches in PATSTAT. This approach allowed us also to identify companies' subsidiaries. We included any subsidiaries directly held to at least 25 percent in our sample. Information on the names of the relevant subsidiaries was derived from LexisNexis (http://www.lexisnexis.com) and Creditreform Amadeus (http://www.creditreform.com). For the identified companies, we extracted data on the annual number of patent filings by year as well as granted patents by the United States Patent and Trademark Office (USPTO). Furthermore, patent forward citations and the average family size were added to the dataset. The priority date-that is, the year of the first worldwide filing-was used for all patents. Because the sample contains missing data on some of the included variables, our final sample consists of 1,348 observations from 155 companies. ${ }^{6}$ We proceed to discuss our variables more in detail.

\title{
Operationalisation
}

\section{Dependent variable}

In our empirical analysis, we use the rating system of Standard \& Poor's, ranging from A+ (highest rating) to D (lowest rating) (see Table I). Thus, our credit rating variable is Standard \& Poor's opinion of a company's overall creditworthiness-that is, its capacity to satisfy its financial obligations. On the basis of their rating scale, we specify our dependent variable.

\author{
Insert Table I here
}

\footnotetext{
${ }^{6}$ An overview of the final sample in terms of size and industry distribution can be found in the annex. A full list of the analyzed 155 companies is available upon request.
} 


\section{Explanatory variables}

For the operationalization of our explanatory variables, we draw upon several earlier studies (Harhoff et al. (2003); Lerner (1994); Narin et al. (1987); Reitzig (2002); Trajtenberg (1990)). Specifically, we rely on three key variables:

Number of granted patents: We use the number of granted patents at the USPTO by priority year (in thousands) as our measure of patenting activity. Because patent stocks are most likely already reflected in a company's rating, we prefer examining patent flows, potentially providing new information about a company's creditworthiness. In our robustness checks, however, we also examine the impact of a company's patent stock. Specifically, we calculate the sum of granted patents within the last five years and apply a 15 percent depreciation rate.

Average number of forward citations: The average number of forward citations a company receives for their granted patents at the USPTO is calculated in a four-year time window. This window is used to ensure that all patents have the same amount of time to be cited, avoiding any potential bias arising from older patents receiving more citations.

Average family size: We follow the DOCDB patent family definition of the EPO (Martinez, 2011). Thus, our family size variable is the number of distinct patent offices the patent was filed at. A prerequisite, however, is that one of the filing offices is the USPTO, as we focus on companies headquartered in the US. We excluded the "singletons" in our calculations (Martinez, 2011), which are patent families that consist of only one family member, to focus solely on patent families with at least one member in another jurisdiction. Having established the family size of the patents in our sample, we calculated the average family size of each company's patent 
portfolio.

\section{Control variables}

We control for several influencing factors on companies creditworthiness, following previous research. In this section, we describe our controls more in detail.

Firm size (sales): Ashbaugh-Skaife et al. (2004) document a strong positive impact of firm size on companies' credit rating. Following, Czarnitzki and Kraft (2004), we control for this using company sales.

ROA (earning before interest and tax (EBIT)/total assets): According to Standard \& Poor's (2008), profitability provides a litmus test for a firms rating. Return on assets (ROA) provides a widely used profitability measurement. As past studies show that ROA has a significant positive impact on companies' rating (Ashbaugh-Skaife et al. (2004)), we control for this in our regressions.

Leverage (total debt/total assets): Rating agencies typically employ leverage ratios to determine the risk that the company will not be able to service its debt (Standard \& Poor's (2008)). Following a vast literature documenting the negative impact leverage may have on a company's creditworthiness (Ashbaugh-Skaife et al. (2004); Horrigan (1966); Pogue and Soldofsky (1969); Pinches and Mingo (1973)), we control for the debt-to-asset ratio of the companies in our sample.

Pay-back period (net debt/EBIT): Rating agencies are also concerned with the payback period over which a company will be able amortize its debt (Standard \& Poor's (2008)). Taking EBIT over the firm's total debt gives us an indicator suggesting how many years the company will need 
to do so. We subtract cash or cash equivalents from the total debt to account for some companies having larger cash reserves that would allow them to amortize some of their debt.

Subordinated debt (dummy variable): Subordinated debt ranks after other debt instruments in the case of liquidation, and is thus riskier for corporate lenders. Following Ashbaugh-Skaife et al. (2004), finding that subordinated debt has a significant negative impact on firms' rating, we include a dummy variable taking the value 1 if the company has any subordinated debt (see also Horrigan (1966); Pinches and Mingo (1973)).

Interest rate (net interest/total debt): We calculate the interest a firm pays to service its debt, following the simple intuition that lenders tend to demand higher interest on high risk debt (Stiglitz and Weiss (1981)). If companies pay higher interest to refinance their debt this will be reflected in their creditworthiness (Standard \& Poor's (2008)).

Short term debt (debt due in one year/total debt): Short term debt imposes a refinancing risk on companies (Standard \& Poor's (2010a)). We control for this by taking the share of a firm's total debt that is due within a year into account.

R\&D expenditures/sales: Following past research showing that $R \& D$ investments signal growth opportunities, annual R\&D expenditures (in billions) enters our empirical model. As larger firms tend to spend more on $R \& D$, the annual $R \& D$ expenditures are normalized by sales.

Insert Table II here 


\section{Estimation methods}

Corporate credit ratings are ordinally scaled, but uniform differences in categories cannot be assumed. As ordinal dependent variables violate the assumptions of the linear regression model (OLS), models that avoid the assumption of equal distances between the categories provide a better choice (Long and Freese (2003)). Therefore, we employ ordered probit models with maximum likelihood (ML) estimation to assess the effects of the patent indicators on corporate credit ratings. Ordered probit models start from a latent variable model with

$$
y_{i}^{*}=x_{i} \beta+\varepsilon_{i} \text { with } \varepsilon_{i} \square N(0,1)
$$

where $y_{i}^{*}$ is the unobserved, latent dependent variable, $x_{i}$ is a vector of explanatory variables, $\beta$ is a coefficient vector and $\varepsilon_{i}$ the normally distributed error term. The dependent variable is limited by thresholds $\mu$ with

$$
y_{i}=\left\{\begin{array}{ll}
0, & \text { if }-\infty<y_{i}^{*} \leq \mu_{0} \\
1, & \text { if } \mu_{0}<y_{i}^{*} \leq \mu_{1} \\
\vdots & \text { if } \mu_{J-1}<y_{i}^{*} \leq \infty
\end{array} \quad \text { with } i=1,2, \ldots n\right.
$$

where $y_{i}$ is the observed categorical corporate credit rating variable, which takes on values of 0 to $\mathrm{J}$.

As we use a firm-level panel for our analyses, we are able to specify to which group each observation belongs. In other words, we can cluster the ordered probit model by companies and thus employ heteroscedasticity-consistent standard errors (White (1980)), allowing us to control for 
unobserved heterogeneity in our models. In addition, we add time- and industry-dummies to the models to account for period- and industry-specific effects. ${ }^{7}$ The coefficients of the ML estimation can be interpreted insofar that positive signs of the coefficients are associated with a higher rating category.

\section{Empirical findings}

\section{Main results}

In this section, we examine our main research questions. Table III documents the pairwise correlations between our variables, revealing a positive relationship between the number of patents a company is granted and its credit rating. ${ }^{8}$ Furthermore, companies with a higher average family size in their patent portfolio also experience higher creditworthiness. Surprisingly, however, patent forward citations and R\&D-intensity is negatively correlated with companies rating. We turn to examining the robustness of these relationships when adding our controls.

\section{Insert Table III here}

Table IV shows the estimates that result from our ordered probit regressions. ${ }^{9}$ Our R\&D intensity

\footnotetext{
${ }^{7}$ Probit models with fixed effects lead to inconsistent estimates (Arellano and Hahn 2007, Fernandez-Val 2007, Greene 2002). We therefore calculated ordered probit models with ML estimation as our main model and included a further OLS model with firm fixed-effects as a robustness test.

${ }^{8}$ For our bivariate analysis we also use polyserial correlations, which use maximum likelihood estimation. These can be used to correlate discrete and continuous variables if the discrete variable measures an underlying continuous latent variable (see for example Olsson et al. (1982)). As can be seen in Table III, however, the results only change slightly when calculating the in this case more accurate polyserial correlations.

${ }^{9}$ We measure the overall fit of the models, using the Bayesion Information Criterion (BIC). The difference in BIC between two models shows which one is better able to explain the variance in the dependent variable. For example, BIC(M1) - BIC(M2) $>0$ leads to a preference of M2 (Long and Freese (2001)). As we can see in Table IV, BIC takes a lower value when adding the innovation and the patent value indicators to the model, implying that M3 is best able to explain the variance in credit rating. The same is true of Akaike's Information Criterion (AIC), which is a similar measure as BIC. All else being equal, the model with the smaller value of AIC can be considered as the model with the better overall fit (Long and Freese (2001)).
} 
variable has a consistently negative impact on companies' credit rating throughout our models. Possibly, this reflects that R\&D projects often are high-risk investments. For example, Kothari et al. (2002) show that the variance of earnings associated with R\&D is substantially higher compared to the variability of earnings related to tangible assets. Furthermore, research expenditures typically reduce profits in the short-run. ${ }^{10}$ Because corporate lenders do not participate on the upside of high-risk investments, while reduced profits may constitute a liquidity problem, R\&D investments may be associated with higher credit risk. Nevertheless, companies granted a higher number of patents experience higher creditworthiness throughout our models. While patents reflect innovation output rather than investments, this finding is difficult to square with the documented negative relationship between $\mathrm{R} \& \mathrm{D}$-intensity and companies rating-something that we discuss in further detail below. Importantly, these findings also contrast those of Czarnitzki and Kraft (2004), implying an inverse U-shaped relationship between patents and companies credit rating (we have examined the possibility of a non-linear relationship by including the squared terms of our R\&D and patent variables, but did not find any evidence in favor of this). ${ }^{11}$

Furthermore, we document a positive relationship between the average family size of a company's patent portfolio and its credit rating, implying that patents filed across several jurisdictions provide better inside collateral. At the same time, however, patent forward citations have a consistent negative impact on corporate credit ratings throughout our models. While previous studies suggest that one forward citation represents a value of about 210.000 USD (Hall et al. (2000)), cited patents are also more likely to be subject to lawsuits (Lanjouw and Schankerman (2001);

\footnotetext{
${ }^{10}$ IAS 38 states that only development costs can be capitalized while research activities are to be treated as expenditures.

${ }^{11}$ Note that our measure of R\&D intensity differs from the innovation performance measures of Griffin et al. (2018), examining patents granted divided by $R \& D$ spending in a given year. While they are interested in the management of intangibles, we focus primarily on investment in such assets.
} 
Harhoff (2003)). Although we are unable to disentangle the mechanisms underlying these effects, the financial consequences of patent lawsuits can be severe. According to estimates by Bessen and Meurer (2008), the average cost of lawsuits for alleged infringers amounts 28.7 million USD. Thus, in a recent press release for example, Standard and Poor's (2010b) disclosed that the noninvestment-grade ratings on AGA Medical Corp. reflect "the company's narrow product line [and] risks posed by competition, regulation, and patent litigation.”

The negative impact of forward citations on companies' creditworthiness may not necessarily be a result of citations providing an indicator for valuable patents. As noted above, family size exhibits a positive relationship with companies rating. However, forward citations equally indicate subsequent $R \& D$ investments in a particular technology, resulting in increased $R \& D$ competition, which in turn may increase the probability of patent litigation. While the number of patents granted to a company has a positive impact on its rating, Lanjouw and Schankerman (2001) have argued that portfolio size effects exist, meaning that firms with a larger patent portfolio are more able to settle disputes through cross-licensing agreements, without resorting to patent lawsuits. This interpretation also offers a possible explanation for why patenting firms experience higher ratings although $R \& D$-intensive companies do not: patents are reflected in companies' creditworthiness not in terms of growth opportunities, but as insurance against future lawsuits. Such an interpretation is consistent with our key findings and the nature of debt contracts.

\section{Insert Table IV here}

Our findings are robust to a number of specifications. First, we examined the above discussed relationships with a one, two and three period lag, respectively, and re-calculated M3 only with the lagged explanatory variables. The results show that our findings remain robust up to a time 
lag of two years. ${ }^{12}$ Furthermore, Wald-Tests for the single coefficients for M3 were conducted (see Table V). The tests show that the coefficients for R\&D and patents are not equal to zero, meaning that we find a significant influence of a combination of our indicators on the credit rating variable, also when we add the patent value indicators to the Wald-Test.

\section{Insert Table V here}

Finally, we analyze the effects of $R \& D$, patents and our patent value indicators on the corporate credit rating variable in more detail across the categories of the dependent variable. This was done by calculating the marginal effects at the means of the independent variables (see Table VI). The findings show that patents are best able to explain the variance in corporate credit ratings in the medium ranges of the dependent variable, i.e. from rating " $\mathrm{C}$ " to rating "A". In the lowest and highest category of the rating variable, our indicators do not exhibit any significant effects. Accordingly, in the lowest category of the credit rating, containing financially distressed companies, other factors affect credit risk more substantially. This is in line with the findings of Griffin et al. (2018), showing that companies innovation performance improve their credit rating, but only for firms with a lower likelihood of default.

The coefficients of our patent value indicators paint a similar picture. The effect of the average family size turns significant only in the $\mathrm{B}$ to $\mathrm{B}+$ categories. The forward citations indicator is negative in the $\mathrm{B}+$ to $\mathrm{A}+$ categories, but insignificant. Nevertheless, this suggests that forward citations are mainly negatively correlated with the creditworthiness of financially stable companies.

\footnotetext{
${ }^{12}$ Since the results of these models only slightly differ to our original specification, they are not shown in detail here. However, the detailed results are available upon request.
} 
Insert Table VI here

\section{Sub-sample analyses and additional robustness checks}

We perform additional sub-sample analyses and robustness checks to test whether our results remain stable over different model specifications (Table VII). All of these analyses are performed on the basis of the final model specification (M3).

\section{Insert Table VII here}

Our first concern is that the stocks of $\mathrm{R} \& \mathrm{D}$ and patents may provide more important determinants of companies' creditworthiness than the annual R\&D expenditures or granted patents. Specifically, companies accumulated innovation activity may be more important to their creditworthiness than annual flows. Following Hall, Jaffe and Trajtenberg (2005), we specify R\&D capital stocks as the sum of a company's R\&D expenditures with a yearly depreciation rate of $15 \%$ divided by a company's sales. For the calculation of the patent stocks, we use the sum of granted patents within the last five years and applied the same depreciation rate. When controlling for stocks of R\&D and patents, Table VII shows that the number of granted patents is still economically and statistically significant. Furthermore, forward citations are still negatively correlated with companies' creditworthiness, but lose significance. Possibly, this reflects that portfolio size effects are predominant, meaning that when accounting for the accumulated patent stock, the risk of lawsuits is less severe.

A second approach to testing the robustness of our results is to replace the annual number of granted patents by the annual number of a company's patent applications. Although this means that we have to trim our sample to the years 2001 to 2007, as information of patent filings at the 
USPTO is not available before 2001, we observe a positively significant effect of patent filings on credit rating. However, the value of the coefficient becomes smaller when patent applications instead of granted patents are used. This is in line with our argumentation that patents can be applied to initiate and defend against lawsuits, which is more effective with granted patents than patent applications. We note however that this may also be a result of granted patents providing better inside collateral. Our patent value indicators do not show any statistically significant effects in this reduced sample.

The third approach towards testing the robustness of our findings was to replace the average number of forward citations with a more refined citation measure, accounting for the fact that citation rates vary across sectors. Specifically, we calculated the ratio between the average number of forward citations received by company and the average number of forward citations within its industry (identified by 2-digit NACE codes). In this model, the industry-normalized citation measure shows a positive, yet non-significant effect on the credit rating variable. Accordingly, whether a company's patent portfolio is cited above or below industry average does not seem to impact directly on its creditworthiness. Rather, this finding suggests that the negative relationship between forward citations and companies credit rating may be driven by industries. Such an interpretation suggests that companies operating within industries where patent lawsuits are common (implied by higher citation rates) experience lower creditworthiness, while the citations received by a particular company is not directly accounted for in credit rating assessments.

At first glance, these findings may seem hard to square with those of Griffin et al. (2018), showing that better innovation performance translate into higher credit worthiness. However, they measure innovation performance as patents and citations divided by R\&D expenditure. In con- 
trast, we are interested in patents as collateral rather than companies efficiency in innovation, which is arguably more important from a creditor perspective. What is more, Griffin et al. (2018) do not explicitly consider the possibility that citations are reflected differently in ratings across industries. To further explore if the negative effect of the forward citation indicator is related to the risk of litigation, we split the companies into a "high litigation risk" and "low litigation risk" risk group according to the industry they are located in. In order to classify the industries according to their litigation risk, we relied on the work of Bessen and Meurer (2005). They have found that firms in retail and wholesale (SIC codes 50-59), instruments (38), electronics (36), and machinery/computers (35) have the highest risk to be sued as an alleged infringer in terms of suits per \$billion R\&D. Firms in chemistry (28) and "other non-manufacturing” (remaining nonmanufacturing SIC codes) have been found to be in the medium risk group. A study by Price Waterhouse Coopers (2017) confirms these results, i.e. chemistry and business/consumer services being at the lower end of scale regarding litigation risk. We thus coded these, as well as the remaining industry groups to the "low litigation risk" group (735 observations, 83 firms), while the other above mentioned industries were coded as having a "high litigation risk" (613 observation, 72 firms).

The results of the models are in favor of our interpretation that the negative effect of forward citations is related to litigation risk, i.e. the negative effect is much more pronounced and significant in the "high litigation risk" group while it is less pronounced and non-significant in the "low litigation risk" group (see Annex Table A-I). Interestingly, the positive effect for the number of granted patents is also non-significant in the "high litigation risk" group, which points to the fact that citations are a better indicator for CRA than patents themselves are. 
To shed some additional light on the relationship between forward citations and corporate credit ratings, we conducted a sub-sample analysis of ICT companies. ${ }^{13}$ We find the ICT sector to be of particular interest, as the risk of patent lawsuits in this sector is relatively high (Cohen et al. (2000)). In this sub-sample, however, both the number of patents granted and the average number of forward citations exhibit a negative, although insignificant, impact on companies rating. Nevertheless, this is possibly a consequence of using a small sub-sample, consisting only of 63 firms. Although the results from this analysis should be interpreted with caution, our findings are consistent with the idea that ICT patents are surrounded by legal uncertainties, and thus associated with potential lawsuits, while providing limited inside collateral to creditors.

Furthermore, we add a variable measuring the technological diversification of a company's patent portfolio. Specifically, we calculated a Herfindahl-Hirschman Index on the average number of IPC-classes (4-digit) of a company's patent portfolio, which shows whether a company is specialized or diversified across different technological fields. Our technological diversification measure does not significantly influence a firm's credit rating (see Table A-I in the annex). In addition, the effects of our core explanatory variables are not affected by the inclusion of this variable.

We also replaced our probit model by an OLS model with firm fixed-effects in order to test whether the results might be driven by the model specification as such. Although this influences our coefficients slightly, the signs of the coefficients as well as their significance remain stable. We thus conclude that our model adequately reflects the relations between the explanatory varia-

\footnotetext{
${ }^{13}$ The ICT sector was defined based on NAICS codes. All firms from our sample that belong to the subsectors Computer and Electronic Product Manufacturing (334), Telecommunications (517), Data Processing, Hosting and Related Services (518) as well as Software Publishers (511210) are included.
} 
bles and credit rating.

Finally, we split our sample between the years 1990 to 1999 and 2000 to 2007, to differentiate the "boom-period" in patenting of the 1990s. Doing so, we find that patents had a stronger impact on companies' creditworthiness in the $1990 \mathrm{~s}$, relative to the $2000 \mathrm{~s}$. The coefficient is not only larger in size for the sub-sample of the 1990s but also turns insignificant when looking at the years from 2000 to 2007 only. This, however, might also be an effect of the legal changes of the American Inventors Protection Act of 1999. Before 2001, rating analysts could only observe granted patents, while after 2001 it was possible also to observe patent filings. Thus, more timely information for a credit assessment was available. This also corresponds to the result above, showing a highly positive relationship between patent filings and corporate credit ratings for the period 2001 to 2007.

\section{Conclusions and policy implications}

In this paper, we examine the relationship between companies' patent portfolios and their credit rating, providing relevant, albeit indirect, evidence on patents as a debt funding mechanism. Doing so, we find that larger patent portfolios are associated with higher credit ratings. Our indicators for valuable patents, however, provide a mixed picture. While there is a positive link between the average family size of a company's patent portfolio and its credit ratings, we surprisingly find a significant negative relationship between patent forward citations and companies ratings. We hypothesize that this finding is the result of citations being associated of patent lawsuits (Lanjouw and Schankerman (2001)), potentially incurring substantial losses on creditors (Bessen and Meurer (2008)). 
Importantly, our findings show that while patents contribute to higher credit ratings, they do not necessarily do so by signaling growth opportunities or providing collateral to corporate lenders. There are three pieces of regression evidence suggesting this. First, we find that R\&D investments-which are equally suggestive of growth opportunities-do not contribute to higher ratings, while patents do. Second, we document that the economic effects of our indicators for valuable patents, providing better inside collateral, are substantially smaller than the effects of a larger patent portfolio. Third, we reveal a negative relationship between forward citations and credit ratings. Thus, the number of patents a company files is more important to its rating than the economic value of those patents, suggesting that corporate lenders should take a different perspective on patents than equity investors. Importantly, as cited patents are more likely to be subject to lawsuits (Lanjouw and Schankerman (2001); Harhoff (2003)), our findings imply that corporate lenders need to make trade-offs between the potential future benefits related to patents and the risk of lawsuits. Theoretically, from a creditor's perspective, risks associated with patent lawsuits will generally outweigh potential economic benefits as creditors do not share the upside related to the firm's investments. At first sight, this may seem contradictory to our findings, showing that the number of patents is associated with higher credit ratings. However, as suggested by Lanjouw and Schankerman (2001), portfolio size effects may exist, meaning that firms with a larger patent portfolio are better able to settle disputes through cross-licensing agreements, without resorting to patent lawsuits. Taking these findings together, we provide suggestive evidence of innovating companies experiencing higher credit ratings as a result of larger patent portfolios providing insurance against potential future lawsuits. We emphasize, however, that more research on the direct relationship between patent lawsuits and companies' credit rating is essential to further disentangle the mechanisms underlying these effects. 
Our findings have important implications for policy. As argued by Lemley and Shapiro (2004): "Under patent law, a patent is no guarantee of exclusion but more precisely a legal right to try to exclude". Together with an ever increasing pace of strategic patenting (Blind et al. (2004); Cohen (2005); Hall and Ziedonis (2001)), this has created a litigious patent environment with substantial costs of patent lawsuits (Bessen and Meurer (2008)), potentially leading corporate lenders to refrain from financing investments in innovation. As companies need to devote substantial financial resources to build and uphold a large patent portfolio as insurance to tap into credit markets, innovation may suffer as a consequence. While further research on the direct link between the risk of patent lawsuits and companies creditworthiness is needed, policymakers would do well in implementing policies to reduce the legal uncertainties surrounding patents. 


\section{References}

Aboody D, Lev B. 2000. Information Asymmetry, R\&D, and Insider Gains, Journal of Finance 55: $2747-2766$.

Aghion P, Bond SR, Klemm A, Marinescu I. 2004. Technology and Financial Structure: Are Innovative Firms Different?, Journal of the European Economic Association 2: 277-88.

Albert MB, Avery D, Narin F, McAllister PR. 1991. Direct validation of citation counts as indicators of industrially important patents, Research Policy 2: 251-259.

Alcacer J, Gittelman M. 2006. Patent citations as a measure of knowledge flows: The influence of examiner citations, Review of Economics and Statistics 88, 774-779.

Alcacer J, Gittelman M, Sampat B. 2009. Applicant and examiner citations in U.S. patents: An overview and analysis, Research Policy 38: 415-427.

Arellano, M.; Hahn, J. (2007): Understanding bias in nonlinear panel models: Some recent developments, Econometric Society Monographs 43, 381, Cambridge University Press.

Ashbaugh-Skaife-Skaife H, Collins DW, LaFond R. 2006. The effects of corporate governance on firms' credit ratings, Journal of Accounting and Economics 42: 203-243.

Audretsch DB, Lehmann EE. 2004. The Effect of Experience, Ownership, and Knowledge on IPO Survival: Evidence from the Neuer Markt, in: Discussion Paper 04(10), Konstanz.

Balasubramanian N, Sivadasan J. 2011. What Happens When Firms Patent? New Evidence from U.S. Economic Census Data, Review of Economics and Statistics 93: 126-146

Barro, RJ. 1976. The Loan Market, Collateral, and Rates of Interest. Journal of Money, Credit, and Banking 8 (4): 439-56.

Barry, C.; Arad, R.; Ansell, L.; Cartier, M.; Lee, H.Y. (2017): 2017 Patent Litigation Study Change on the horizon?, Price Waterhouse Coopers, May 2017

Bernanke, B, Gertler, M. 1989. Agency Costs, Net Worth, and Business Fluctuations. American Economic Review 79 (1): 14-31.

Bessen, J.; Meurer, M. J. (2005): The Patent Litigation Explosion, Boston University, School of Law, Working Paper Series, Law and Economics, Working Paper No. 05-18

Bessen JE, Meurer MJ. 2008. The Private Costs of Patent Litigation, Working Paper Series, Law and Economics Working Paper 7(8), Boston University School of Law.

Blind K, Cremers K, Mueller E. 2009. The Influence of Strategic Patenting on Companies' Pa- 
tent Portfolios, Research Policy 38: 428-436.

Blind K, Edler J, Frietsch R, Schmoch U. 2004. The patent upsurge in Germany: the outcome of a multi-motive game induced by large companies. Working paper presented at the Eighth Schumpeter Conference in Milan, Karlsruhe. Fraunhofer Institute Systems and Innovation Research (ISI).

Blind, K, Edler J, Frietsch R, and Schmoch U. 2006, Motives to patent: Empirical Evidence from Germany, Research Policy 35: 655-672

Bloom N, van Reenen J. 2002. Patents, Real Options and Firm Performance, The Economic Journal 112: 97-116.

Carpenter MP, Narin F, Woolf P. 1981. Citation rates to technologically important patents, World Patent Information 3: 160-163.

Carpenter RE, Petersen BC. 2002. Capital Market Imperfections, High-Tech Investment, and New Equity Financing, The Economic Journal 112: 54-72.

Cockburn I, MacGarvie, M.J. (2009) Patents, Thickets and the Financing of Early-Stage Firms: Evidence from the Software Industry. Journal of Economics \& Management Strategy, 18: 729773

Cockburn I, Wagner S. 2010. Patents and the survival of Internet-related IPOs. Research Policy, 39(2): 214-228.

Cohen WM. 2005. Patents and appropriation, Journal of Technology Transfer 30: 57-71.

Cohen, WM, Nelson, RR, Walsh, JP. (2000): Appropriability Conditions and Why Firms Patent and Why They Do Not, Working Paper 7552: National Bureau of Economic Research.

Cohen WM, Goto A, Nagata A, Nelson RR, Walsh, JP. 2002. R\&D spillovers, patents and the incentives to innovate in Japan and the United States, Research Policy 31: 1349-1367.

Czarnitzki D, Kraft K. 2004. Innovation indicators and corporate credit ratings: evidence from German firms, Economic Letters 82: 377-384.

Eberhardt AC, Maxwell WF, Siddique AR. 2004. An Examination of Long-Term Abnormal Stock Returns and Operating Performance Following R\&D Increases, The Journal of Finance 59: 623-650.

Fernandez-Val, I. (2007): Fixed effects estimation of structural parameters and marginal effects in panel probit models, Journal of Econometrics, 2009, vol. 150, issue 1, 71-85

Frietsch R, Schmoch U, van Looy B, Walsh JP, Devroede R, Du Mariëtte P, Jung T, Meng Y, Neuhaeusler P, Peeters B, and Schubert T. 2010. The Value and Indicator Function of Patents, Studien zum deutschen Innovationssystem, Nr. 15/2010: Expertenkommission Forschung und 
Innovation (EFI).

Frey, CB (2013): Intellectual Property Rights and the Financing of Technological Innovation: Public Policy and the Efficiency of Capital Markets. Cheltenham: Edward Elgar Publishing, 2013.

Gambardella A, Harhoff D, Verspagen B. 2008. The value of European patents, European Management Review 5: 69-84.

Greene, W. (2002): The Bias of the Fixed Effects Estimator in Nonlinear Models, Department of Economics, Stern School of Business, New York University, October 2002.

Greenhalgh CA, Longland M. 2005. Running to stand still? - The value of R\&D, patents and trade marks in innovating manufacturing firms, International Journal of the Economics of Business 12: 307-328.

Griffin, Paul A., Hyun A. Hong, and Ji Woo Ryou. Corporate innovative efficiency: Evidence of effects on credit ratings. Journal of Corporate Finance 51 (2018): 352-373.

Griliches, Z. 1981. Market value, R\&D and patents. Economics Letters 7: 183-87.

Griliches, Z. 1990. Patent Statistics as Economic Indicators. NBER Working Paper No. 3301.

Grindley P, Teece DJ. 1997. Managing Intellectual Capital: Licensing and Cross-licensing in Semiconductors end Electronics, California Management Review 39: 8-41.

Hall BH. 2002. The Financing of Research and Development, Oxford Review of Economic Policy 18: 35-51.

Hall BH, Jaffe AB, Trajtenberg M. 2005. Market value and patent citations, Rand Journal of Economics 36 (1), 16-38.

Hall BH, Lerner J. 2010. The Financing of R\&D and Innovation, in: Hall BJ, Rosenberg N. ed.: Handbook of the Economics of Innovation (Elsevier-North Holland).

Hall BH, Ziedonis RH. 2001. The patent paradox revisited: an empirical study of patenting in the U.S. semiconductor industry 1979-1995, Rand Journal of Economics 36: 101-128.

Harhoff, Dietmar, 1998, Are There Financing Constraints for R\&D and Investment in German Manufacturing Firms?, Annales d'Economie et de Statistique 49/50, 421-56.

Harhoff, Dietmar, Francis Narin, Frederic M. Scherer, and Katrin Vopel, 1999, Citation Frequency and the Value of Patented Inventions, Review of Economics and Statistics 81, 511-515.

Harhoff D, Scherer FM, Vopel K. 2003. Citations, Family Size, Opposition and the Value of Patent Rights, Research Policy 32: 1343-1363. 
Hart, O., Moore J. 1994. A Theory of Debt Based on the Inalienability of Human Capital. Quarterly Journal of Economics 109 (4): 841-79.

Helmers C, Rogers ML 2010. Innovation and the survival of new firms in the UK, Review of Industrial Organisation 136: 227-248.

Horrigan JO. 1966. The Determination of Long-Term Credit Standing with Financial Ratios, Journal of Accounting Research 4: 44-62.

Hsu, Po-Hsuan, Hsiao-Hui Lee, Alfred Zhu Liu, and Zhipeng Zhang. Corporate innovation, default risk, and bond pricing. Journal of Corporate Finance 35 (2015): 329-344.

Jaffe, A.B., Trajtenberg M. (2002) Patents, citations, and innovations: A window on the knowledge economy. MIT press.

Jensen MC, Meckling WH. 1976. Theory of the firm: managerial behavior, agency costs and ownership structure, Journal of Financial Economics 3: 305-360.

Jensen P.H., Webster E., and Buddelmeyer H. 2008. Innovation, Technological Conditions and New Firm Survival. The Economic Record, 84(267): 434-448.

Kothari SP, Laguerre TE, Leone AJ. 2002. Capitalization versus Expensing: Evidence on the Uncertainty of Future Earnings from Capital Expenditures versus R\&D Outlays, Review of Accounting Studies 7: 355-382.

Kiyotaki N., Moore J. 1997. Credit Cycles. Journal of Political Economy 105 (2):211-48.

Lanjouw JO, Schankerman M. 2001. Characteristics of Patent Litigation: A Window on Competition, Rand Journal of Economics 32: 129-151.

Lanjouw JO, Schankerman M. 2004. Patent Quality and Research Productivity: Measuring Innovation with Multiple Indicators, The Economic Journal 114: 441-65.

Lemley MA, Shapiro C. 2005. Probabilistic Patents, Journal of Economic Perspectives 19: 7598.

Lerner J. 1994. The importance of patent scope: An empirical analysis, The Rand Journal of Economics 25: 19-333.

Lev B. 2000. Intangibles: Management, measurement, and reporting. Brookings Institution Press.

Long JS, Freese J. 2003. Regression Models for Categorical Dependent Variables using Stata, Revised Edition, College Station (Texas: Stata Press).

Loumioti M. 2012. The Use of Intangible Assets as Loan Collateral. Working paper, University of Southern California. 
Martínez C. 2011. Patent families: When do different definitions really matter?, Scientometrics 86: 39-63.

Masters, B. 2011. Banks eye intangible assets as collateral. The Financial Times 11. June.

Myers SC, Majluf NS. 1984. Corporate financing and investment decisions when firms have information that investors do not have, Journal of Financial Economics 13: 187-221.

Narin F, Noma E, Perry R. 1987. Patents as indicators of corporate technological strength, Research Policy 16: 143-155.

O'Brien RM. 2007. A Caution Regarding Rules of Thumb for Variance Inflation Factors, Quality \& Quantity 41: 673-690.

Olsson UL, Drasgow F, Dorans NJ. 1982. The polyserial correlation coefficient, Psychometrika 47: 337-347.

Pakes AS. 1986. Patents as Options: Some Estimates of the Value of Holding European Patent Stocks, Econometrica 54: 755-784.

Pinches GE, Mingo KA. 1973. A Multivariate Analysis of Industrial Bond Ratings, The Journal of Finance 28: 1-18.

Pitkethly RH. 2001. Intellectual Property Strategies in Japanese and UK Firms: Patent Licensing Decision and Learning Opportunities, Research Policy 30: 425-442

Pogue TF, Soldofsky RM. 1969. What is in a Bond Rating, Journal of Financial and Quantitative Analysis 4: 201-228.

Putnam JD. 1996. The value of international patent rights, Yale University.

Rajan RG, Zingales L. 1995. What Do We Know about Capital Structure? Some Evidence from International Data, Journal of Finance 50: 1421-60.

Reitzig M. 2002. Die Bewertung von Patentrechten: Eine theoretische und empirische Analyse aus Unternehmenssicht (Wiesbaden: Dt. Univ.-Verl.).

Reitzig M. 2004: The Private Value of "Thickets" and "Fences": Towards an updated Picture of the use of Patents across Industries, Economics of Innovation and New Technology 13: 457-476.

Standard \& Poor's 2008. Corporate Credit Rating Criteria (www.corporatecriteria.standardandpoors.com)

Standard \& Poor's 2010a. Refinancing Risk Remains The Main Threat To The Credit Quality Of European Speculative-Grade Companies, Ratings Direct.

Standard \& Poor's 2010b. Medical Corp. Ratings Off CreditWatch; Outlook Stable, 'B+' Corpo- 
rate Credit Rating Affirmed. Press release 10 April.

Standard \& Poor's 2013. Key Credit Factors For The Health Care Equipment Industry, Ratings Direct.

Stliglitz JE. 1985. Credit Markets and the Control of Capital, Journal of Money, Credit, and Banking 17, 133-152.

Stliglitz JE, Weiss A. 1981. Credit Rationing in Markets with Imperfect Information, American Economic Review 71: 393-410.

Trajtenberg, M. 1990. A penny for your quotes: patent citations and the value of innovation, Rand Journal of Economics 21: 172-187.

United States Patent and Trademark Office 2002. Performance and Accountability Report for Fiscal Year 2002, United States Patent and Trademark Office.

White H. 1980. A Heteroskedasticity-Consistent Covariance Matrix Estimator and a Direct Test for Heteroskedasticity, Econometrica 48: 817-838. 
Table I: Detailed summary of the dependent variable

\begin{tabular}{lrrr} 
Corporate Credit Rating & Category & Frequency & Percent \\
\hline D & 1 & 39 & 2.89 \\
C & 2 & 168 & 12.46 \\
B- & 3 & 168 & 12.46 \\
B & 4 & 283 & 20.99 \\
B + & 5 & 320 & 23.74 \\
A- & 6 & 133 & 9.87 \\
A & 7 & 90 & 6.68 \\
A & 8 & 147 & 10.91 \\
\hline
\end{tabular}

Source: Own calculations

Note: Only the number of cases that are used in the multivariate regressions are reported.

Table II: Overview of the variables and summary statistics

\begin{tabular}{lrrrrrr}
\hline Variable & Mean & Std. Dev. & Min & Max & \# Obs. & \# Firms \\
\hline Corporate Credit Rating & 4.61 & 1.87 & 1.00 & 8.00 & 1348 & 155 \\
Return on assets (ROA) & 0.10 & 0.09 & -0.61 & 0.40 & 1348 & 155 \\
Total debt/Total assets & 0.19 & 0.14 & 0.00 & 1.44 & 1348 & 155 \\
Net debt/EBIT & 2.32 & 34.39 & -365.49 & 892.97 & 1348 & 155 \\
Subordinated debt (dummy variable) & 0.09 & 0.28 & 0.00 & 1.00 & 1348 & 155 \\
Debt due in 1 year/Total debt & 0.12 & 0.18 & 0.00 & 1.00 & 1348 & 155 \\
Net Interest/Total Debt & 0.16 & 1.05 & 0.00 & 33.96 & 1348 & 155 \\
Sales (in billions) & 10.27 & 17.79 & 0.11 & 184.88 & 1348 & 155 \\
R\&D expenditures/sales & 0.09 & 0.10 & 0.00 & 0.99 & 1348 & 155 \\
Number of granted patents & 0.22 & 0.44 & 0.00 & 4.58 & 1348 & 155 \\
Average family size & 5.69 & 2.94 & 2.00 & 28.03 & 1348 & 155 \\
Average \# of forward citations & 3.94 & 3.36 & 0.00 & 22.86 & 1348 & 155 \\
\hline Source: Own
\end{tabular}

Source: Own calculations

Note: The summary statistics are only reported for the number of cases that are used in the multivariate regressions. 
Table III: Pairwise correlations for the corporate credit rating measures and innovation indicators

\begin{tabular}{llcc}
\hline & & & \\
& Pairwise correlation & Pairwise polyserial correlation \\
\cline { 2 - 3 } Return on assets (ROA) & & Rho & S.E. \\
\cline { 2 - 3 } Total debt/total assets & $0.37^{* * *}$ & 0.435 & 0.023 \\
Net debt/EBIT & -0.036 & -0.055 & 0.035 \\
Subordinated debt (dummy variable) & 0.008 & 0.017 & 0.055 \\
Debt due in 1 year/Total debt & $-0.144^{* * *}$ & -0.267 & 0.044 \\
Net Interest/Total Debt & $-0.065^{* *}$ & -0.090 & 0.035 \\
Sales & -0.036 & -0.030 & 0.019 \\
R\&D expenditures/sales & $0.208^{* * *}$ & 0.227 & 0.042 \\
Number of granted patents & $-0.351^{* * *}$ & -0.352 & 0.035 \\
Average family size & $0.0463^{*}$ & 0.025 & 0.018 \\
Average \# of forward citations & $0.182^{* * *}$ & 0.198 & 0.026 \\
\hline Source: Own calculations & $-0.099^{* * *}$ & -0.173 & 0.048 \\
\hline
\end{tabular}

Source: Own calculations

Significance Level: $* * * \mathrm{p}<0.01, * * \mathrm{p}<0.05,{ }^{*} \mathrm{p}<0.1$

Notes: Correlation coefficients are only calculated for the observations used in the multivariate regressions. Significance levels are not available for the polyserial correlation coefficients. Therefore only the standard errors are reported. In case of the subordinated debt variable, the correlation coefficient is polychoric rather than polyserial since both variables are categorical. 
Table IV: Results of the ordered probit models

\begin{tabular}{|c|c|c|c|c|c|c|c|c|c|}
\hline \multirow{2}{*}{$d V=$ Corporate Credit Rating } & \multicolumn{3}{|c|}{ M1 } & \multicolumn{3}{|c|}{ M2 } & \multicolumn{3}{|c|}{ M3 } \\
\hline & Coef. & & S.E. & Coef. & & S.E. & Coef. & & S.E. \\
\hline Return on assets & 4.051 & $* * *$ & 0.809 & 3.261 & $* * *$ & 0.84 & 3.203 & $* * *$ & 0.829 \\
\hline Total debt/Total assets & -0.114 & & 0.486 & -0.08 & & 0.454 & -0.106 & & 0.457 \\
\hline Net debt/EBIT & 0.0004 & & 0.0005 & 0.0002 & & 0.0005 & 0.0003 & & 0.0005 \\
\hline Subordinated debt (dummy variable) & -0.774 & $* * *$ & 0.222 & -0.806 & $* * *$ & 0.208 & -0.804 & $* * *$ & 0.207 \\
\hline Debt due in 1 year/Total debt & 0.014 & & 0.296 & 0.051 & & 0.304 & 0.041 & & 0.302 \\
\hline Net Interest/Total Debt & -0.058 & $* * *$ & 0.018 & -0.056 & $* * *$ & 0.017 & -0.055 & $* * *$ & 0.017 \\
\hline Sales (in billions) & 0.023 & $* * *$ & 0.008 & 0.019 & $* * *$ & 0.007 & 0.018 & $* * *$ & 0.007 \\
\hline R\&D expenditures/sales & & & & -2.129 & $* *$ & 0.828 & -2.12 & $* *$ & 0.827 \\
\hline Number of granted patents & & & & 0.315 & $*$ & 0.186 & 0.365 & $* *$ & 0.182 \\
\hline Average family size & & & & & & & 0.044 & $*$ & 0.025 \\
\hline Average \# of forward citations & & & & & & & -0.039 & $*$ & 0.023 \\
\hline Time Dummies & \multicolumn{3}{|c|}{ YES } & \multicolumn{3}{|c|}{ YES } & \multicolumn{3}{|c|}{ YES } \\
\hline Industry Dummies & \multicolumn{3}{|c|}{ YES } & \multicolumn{3}{|c|}{ YES } & \multicolumn{3}{|c|}{ YES } \\
\hline Nr. of observations & \multicolumn{3}{|c|}{1348} & \multicolumn{3}{|c|}{1348} & \multicolumn{3}{|c|}{1348} \\
\hline Nr. of companies & \multicolumn{3}{|c|}{155} & \multicolumn{3}{|c|}{155} & \multicolumn{3}{|c|}{155} \\
\hline Pseudo $\mathrm{R}^{2}$ & \multicolumn{3}{|c|}{0.190} & \multicolumn{3}{|c|}{0.199} & \multicolumn{3}{|c|}{0.202} \\
\hline $\mathrm{AIC}$ & \multicolumn{3}{|c|}{4326.228} & \multicolumn{3}{|c|}{4282.698} & \multicolumn{3}{|c|}{4268.705} \\
\hline $\mathrm{BIC}$ & \multicolumn{3}{|c|}{4550.102} & \multicolumn{3}{|c|}{4516.985} & \multicolumn{3}{|c|}{4513.404} \\
\hline
\end{tabular}

Source: Own calculations

Significance Level: $* * * \mathrm{p}<0.01, * * \mathrm{p}<0.05, * \mathrm{p}<0.1$

Note: The number of observations in each model was adjusted to the model with the fewest observations (M3) in order to conserve comparability of the effects over all models. To test for multicollinearity between the explanatory variables, Variance Inflation Factors (VIFs) based on an OLS model with "corporate credit rating" as the dependent variable were calculated. The ROA variable had the highest VIF (1.39). The mean VIF for the model was 1.19. Hence, we find no multicollinearity concerns (O'Brien (2007).

Table V: Wald-Tests for the innovation and patent value indicators

\begin{tabular}{clr}
\hline R\&D expenditures/sales, Number of granted patents $=0$ & $\mathrm{Chi}^{2}$ & 11.48 \\
& Prob $>\mathrm{Chi}^{2}$ & 0.003 \\
\hline \multirow{2}{*}{ R\&D expenditures/sales, Number of granted patents, Average family size, Aver- } & & $\mathrm{Chi}^{2}$ \\
age \# of forward citations $=0$ & ${\text { Prob }>\mathrm{Chi}^{2}}^{2}$ & 15.43 \\
\hline
\end{tabular}

Source: Own calculations

Note: The Wald-Tests are based on the results of M3. 
Table VI: $\quad$ Marginal Effects calculated at the means of the independent variables (M3)

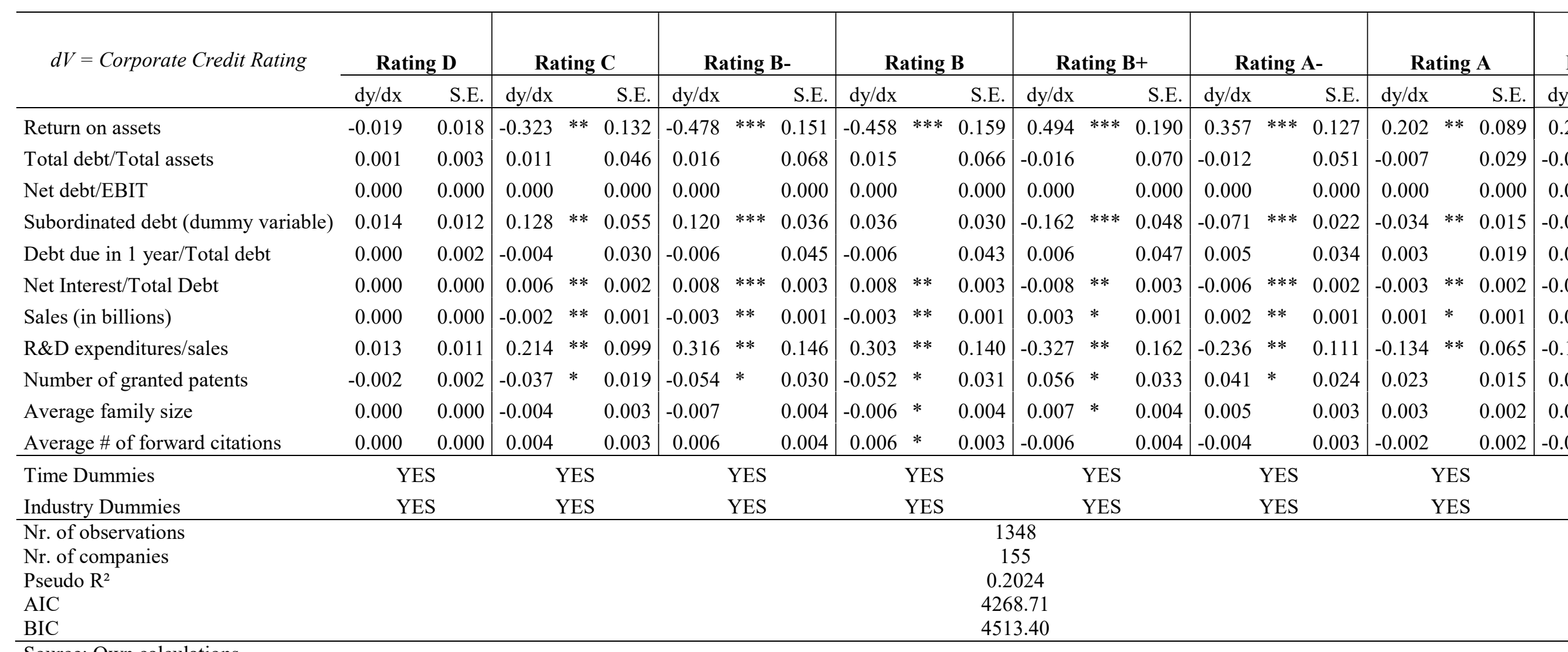

Source: Own calculations

Significance Level: $* * * \mathrm{p}<0.01, * * \mathrm{p}<0.05, * \mathrm{p}<0.1$

Note: Marginal Effects are calculated on the base of M3. For dummy variables, dy/dx is for a discrete change of dummy variable from 0 to 1 . 
Table VII: Coefficients of the explanatory variables for the modified models

\begin{tabular}{llll}
\hline Description of changes to the original specification & $\begin{array}{l}\text { Number of granted } \\
\text { patents }\end{array}$ & $\begin{array}{l}\text { Average } \\
\text { family size }\end{array}$ & $\begin{array}{l}\text { Average \# of for- } \\
\text { ward citations }\end{array}$ \\
\hline M3 (original specification) & $0.365^{* *}$ & $0.044^{*}$ & $-0.039^{*}$ \\
R\&D/sales stock \& stock of granted patents & $0.087^{*}$ & 0.029 & -0.036 \\
\hline Patent applications instead of granted patents, 2001- & & & 0.016 \\
2007 & $0.253^{* *}$ & 0.052 & 0.013 \\
Avg. number of citations in relation to industry average & $0.351^{*}$ & $0.045^{*}$ & $-0.038^{*}$ \\
Model including a technological diversification variable & $0.346^{*}$ & $0.046^{*}$ & $-0.0467^{*}$ \\
\hline OLS with firm fixed-effects instead of probit & $0.512^{* *}$ & $0.055^{*}$ & -0.038 \\
\hline Only for firms in industries with low litigation risk & $0.292^{* *}$ & 0.030 & $-0.113^{* * *}$ \\
Only for firms in industries with high litigation risk & -0.471 & 0.050 & -0.025 \\
\hline ICT firms only & -0.488 & 0.037 & -0.048 \\
Years 1990-1999 & $0.609^{* *}$ & 0.053 & -0.005 \\
\hline Years 2000-2007 & 0.216 & 0.049 & \\
\hline
\end{tabular}

Source: Own calculations

Significance Level: $* * * \mathrm{p}<0.01, * * \mathrm{p}<0.05, * \mathrm{p}<0.1$

Note: Only the coefficients for the relevant explanatory variables are shown. The full results of the models can be consulted in Table A-I in the annex. 
Annex Table A-I: $\quad$ Distribution of the sample: Firm size

\begin{tabular}{lrrrr}
\hline Number of employees & Obs. & \% & Firms & \% \\
\hline $0-9,999$ & 261 & 19.48 & 62 & 28.97 \\
$10,000-49,999$ & 571 & 42.61 & 83 & 38.79 \\
$50,000-99,999$ & 300 & 22.39 & 42 & 19.63 \\
100,000 and more & 208 & 15.52 & 27 & 12.62 \\
\hline Total & $\mathbf{1 3 4 0}$ & $\mathbf{1 0 0}$ & $\mathbf{2 1 4}$ & $\mathbf{1 0 0}$ \\
\hline
\end{tabular}

Source: Own calculations

Note: The number of firms exceeds the aforementioned 155 firms $(100 \%)$ in total because the number of employees is not fixed over time and might change in each firm/year. If a firm grows between two time periods and exceeds the group threshold in the later year, the firm is counted once for year $t$ and once for year $\mathrm{t}+1$. This can lead to double-counts for this representation in terms of the number of firms. 


\section{Annex Table A-II: $\quad$ Distribution of the sample: Sector (NAICS)}

\begin{tabular}{|c|c|c|c|c|c|}
\hline $\begin{array}{l}\text { NAICS- } \\
\text { Code }\end{array}$ & NAICS-Sector & Obs. & $\%$ & Firms & $\%$ \\
\hline 213 & Support Activities for Mining & 11 & 0.82 & 1 & 0.65 \\
\hline 237 & Heavy and Civil Engineering Construction & 5 & 0.37 & 1 & 0.65 \\
\hline 311 & Food Manufacturing & 12 & 0.89 & 2 & 1.29 \\
\hline 322 & Paper Manufacturing & 44 & 3.26 & 4 & 2.58 \\
\hline 324 & Petroleum and Coal Products Manufacturing & 28 & 2.08 & 3 & 1.94 \\
\hline 325 & Chemical Manufacturing & 308 & 22.85 & 32 & 20.65 \\
\hline 326 & Plastics and Rubber Products Manufacturing & 17 & 1.26 & 1 & 0.65 \\
\hline 331 & Primary Metal Manufacturing & 11 & 0.82 & 1 & 0.65 \\
\hline 332 & Fabricated Metal Product Manufacturing & 6 & 0.45 & 1 & 0.65 \\
\hline 333 & Machinery Manufacturing & 120 & 8.9 & 12 & 7.74 \\
\hline 334 & Computer and Electronic Product Manufacturing & 409 & 30.34 & 50 & 32.26 \\
\hline 335 & Electrical Equipment, Appliance, and Component Manufacturing & 45 & 3.34 & 4 & 2.58 \\
\hline 336 & Transportation Equipment Manufacturing & 155 & 11.5 & 15 & 9.68 \\
\hline 337 & Furniture and Related Product Manufacturing & 2 & 0.15 & 1 & 0.65 \\
\hline 339 & Miscellaneous Manufacturing & 41 & 3.04 & 5 & 3.23 \\
\hline 424 & Merchant Wholesalers, Nondurable Goods & 6 & 0.45 & 1 & 0.65 \\
\hline 454 & Nonstore Retailers & 5 & 0.37 & 1 & 0.65 \\
\hline 511 & Publishing Industries (except Internet) & 42 & 3.12 & 10 & 6.45 \\
\hline 517 & Telecommunications & 13 & 0.96 & 2 & 1.29 \\
\hline 518 & Data Processing, Hosting, and Related Services & 2 & 0.15 & 1 & 0.65 \\
\hline 541 & Professional, Scientific, and Technical Services & 56 & 4.15 & 5 & 3.23 \\
\hline 561 & Administrative and Support Services & 3 & 0.22 & 1 & 0.65 \\
\hline 999 & Missing & 7 & 0.52 & 1 & 0.65 \\
\hline Total & & 1348 & 100 & 155 & 100 \\
\hline
\end{tabular}

Source: Own calculations 


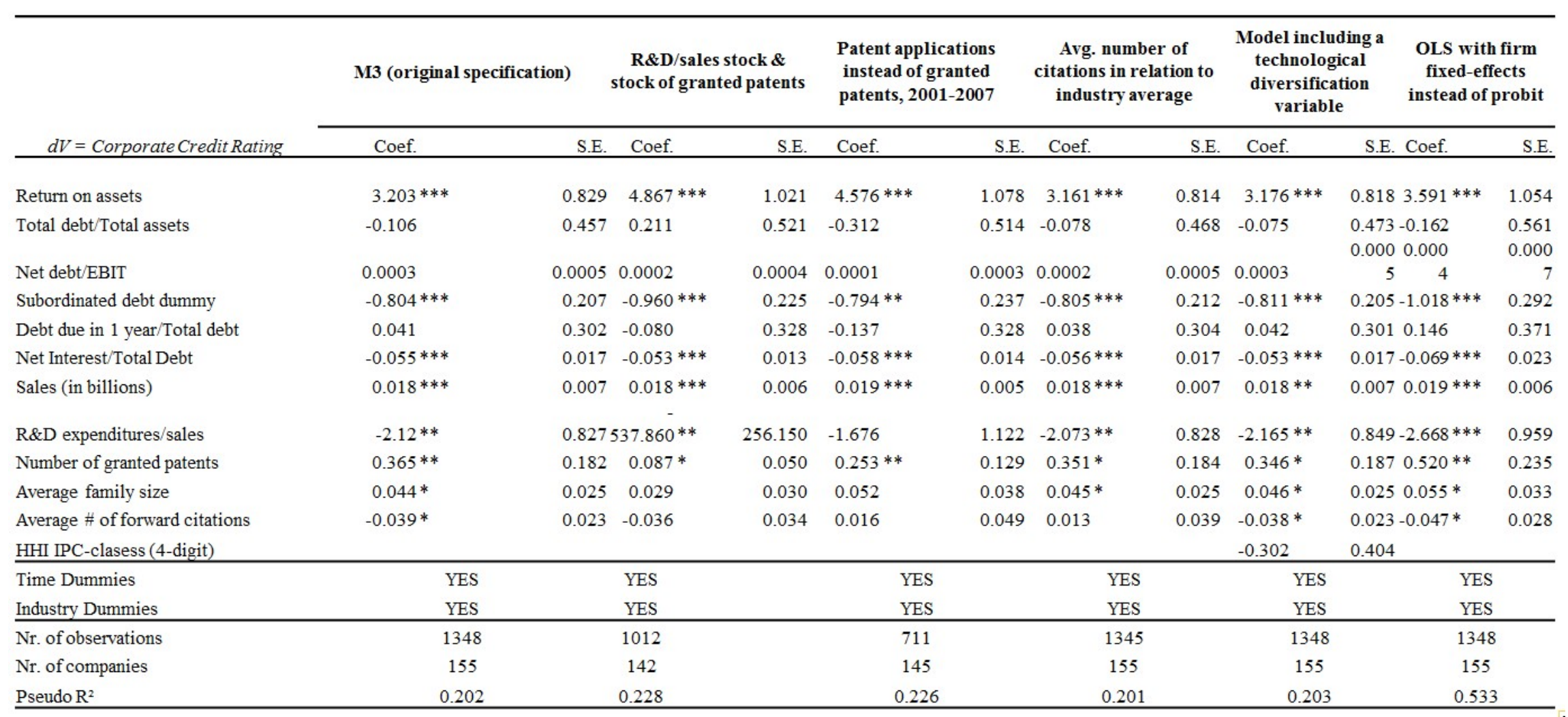

Source: Own calculations

Significance Level: $* * *_{\mathrm{p}}<0.01, * * \mathrm{p}<0.05,{ }^{*} \mathrm{p}<0.1$ 


\begin{tabular}{|c|c|c|c|c|c|c|c|c|c|c|}
\hline \multirow[b]{2}{*}{$d V=$ Corporate Credit Rating } & \multicolumn{2}{|c|}{$\begin{array}{l}\text { Only for firms in industries with } \\
\text { low litigation risk }\end{array}$} & \multicolumn{2}{|c|}{$\begin{array}{l}\text { Only for firms in } \\
\text { industries with high } \\
\text { litigation risk }\end{array}$} & \multicolumn{2}{|c|}{ ICT firms only } & \multicolumn{2}{|c|}{ Years 1990-1999 } & \multicolumn{2}{|c|}{ Years 2000-2007 } \\
\hline & Coef. & S.E. & Coef. & S.E. & Coef. & S.E. & Coef. & S.E. & Coef. & S.E. \\
\hline Return on assets & $5.204 * * *$ & 1.306 & $3.442 * * *$ & 1.131 & $2.038 *$ & 1.092 & $3.330 * * *$ & 1.222 & $3.720 * * *$ & 0.940 \\
\hline Total debt/Total assets & -0.006 & 0.721 & $1.783 *$ & 0.975 & -0.349 & 0.665 & 0.190 & 0.942 & -0.226 & $\begin{array}{l}0.491 \\
0.000\end{array}$ \\
\hline Net debt/EBIT & 0.000 & 0.001 & 0.0000 & 0.0009 & 0.0000 & 0.0005 & $0.0050 *$ & 0.0026 & -0.0002 & 3 \\
\hline Subordinated debt dummy & $-1.174 * * *$ & 0.286 & -0.578 & 0.368 & -0.253 & 0.297 & $-0.846 * * *$ & 0.266 & $-0.791 * * *$ & 0.224 \\
\hline Debt due in 1 year/Total debt & $-0.815 *$ & 0.483 & $0.961 *$ & 0.495 & -0.042 & 0.410 & 0.701 & 0.684 & -0.019 & 0.325 \\
\hline Net Interest/Total Debt & $-0.054 * * *$ & 0.016 & -0.101 & 0.089 & -0.087 & 0.064 & -0.394 & 0.264 & $-0.055 * * *$ & 0.014 \\
\hline Sales (in billions) & $0.015 *$ & 0.008 & $0.023 *$ & 0.013 & $0.047 * *$ & 0.019 & 0.012 & 0.012 & $0.019 * * *$ & 0.006 \\
\hline R\&D expenditures/sales & $-2.006 * *$ & 0.715 & $-6.458 * *$ & 2.828 & $-4.183 *$ & 2.467 & $-2.659 * *$ & 1.327 & $-2.047^{* *}$ & 1.011 \\
\hline Number of granted patents & $0.292 * *$ & 0.135 & -0.471 & 0.333 & -0.488 & 0.374 & $0.609 * *$ & 0.245 & 0.216 & 0.161 \\
\hline Average family size & 0.030 & 0.030 & 0.050 & 0.056 & 0.037 & 0.040 & 0.053 & 0.033 & 0.049 & 0.036 \\
\hline Average \# of forward citations & -0.038 & 0.032 & $-0.113 * * *$ & 0.042 & -0.025 & 0.035 & -0.048 & 0.035 & -0.005 & 0.035 \\
\hline \multicolumn{11}{|l|}{ HHI IPC-clasess (4-digit) } \\
\hline Time Dummies & \multicolumn{2}{|c|}{ YES } & \multicolumn{2}{|c|}{ YES } & \multicolumn{2}{|c|}{ YES } & \multicolumn{2}{|c|}{ YES } & \multicolumn{2}{|l|}{ YES } \\
\hline Industry Dummies & \multicolumn{2}{|c|}{ YES } & \multicolumn{2}{|c|}{ YES } & \multicolumn{2}{|c|}{ YES } & \multicolumn{2}{|c|}{ YES } & \multicolumn{2}{|l|}{ YES } \\
\hline Nr. of observations & \multicolumn{2}{|c|}{735} & \multicolumn{2}{|c|}{613} & \multicolumn{2}{|c|}{466} & \multicolumn{2}{|l|}{515} & \multicolumn{2}{|l|}{833} \\
\hline Nr. of companies & \multicolumn{2}{|c|}{83} & \multicolumn{2}{|c|}{72} & \multicolumn{2}{|c|}{63} & \multicolumn{2}{|l|}{90} & \multicolumn{2}{|l|}{151} \\
\hline Pseudo $\mathrm{R}^{2}$ & \multicolumn{2}{|c|}{0.107} & \multicolumn{2}{|c|}{0.153} & \multicolumn{2}{|c|}{0.242} & \multicolumn{2}{|c|}{0.202} & \multicolumn{2}{|l|}{0.216} \\
\hline
\end{tabular}

Source: Own calculations

Significance Level: $* * * \mathrm{p}<0.01, * * \mathrm{p}<0.05, * \mathrm{p}<0.1$ 
